\title{
Air temperature and winter mortality: Implications for the persistence of the invasive mussel, Perna viridis in the intertidal zone of the south-eastern United States
}

Firth, Louise

http://hdl.handle.net/10026.1/12047

10.1016/j.jembe.2011.02.007

Journal of Experimental Marine Biology and Ecology

Elsevier BV

All content in PEARL is protected by copyright law. Author manuscripts are made available in accordance with publisher policies. Please cite only the published version using the details provided on the item record or document. In the absence of an open licence (e.g. Creative Commons), permissions for further reuse of content should be sought from the publisher or author. 
1 MANUSCRIPT TYPE: New data paper

3 TITLE: Air temperature and winter mortality: implications for the persistence of the

4 invasive mussel, Perna viridis in the intertidal zone of the south-eastern United States

6 AUTHORS:

7 Louise B. Firth ${ }^{\mathrm{a}, \mathrm{b}}$

8 Antony M. Knights ${ }^{\mathrm{c}, \mathrm{d}}$

$9 \quad$ Susan S. Bell ${ }^{\mathrm{a}}$

11 a Department of Integrative Biology, University of South Florida, 4202 East Fowler

12 Avenue, Tampa, FL 33620-5550, USA

$13{ }^{\mathrm{b}}$ Current address: School of Ocean Sciences, Bangor University, Menai Bridge,

14 Anglesey, LL59 5AB, United Kingdom

$15{ }^{\mathrm{c}}$ Department of Marine Science, Coastal Carolina University, Conway, SC 29528, USA

$16{ }^{\mathrm{d}}$ Current address: School of the Environment, University of Liverpool, Biosciences

17 Building, Crown Street, Liverpool, L69 7ZB, United Kingdom

18

* Corresponding author: 1.firth@bangor.ac.uk, tel (+44) 01248388859

\section{KEY WORDS:}

24 climate, weather, cold thermal stress, invasion success, biotic homogenisation 


\section{Abstract}

33 Global climate change and invasive species represent two of the biggest threats to the

34 environment. Biological communities are responding to global climate change through

35 poleward shifts in distribution, and changes in abundance and phenology of both native

36 and non-native species. An increase in the frequency and magnitude of extreme weather

37 events is predicted with global climate change. Much is known about mortality events of

38 marine organisms in relation to warm thermal stress with relatively little known about

39 cold thermal stress, particularly in the tropics. Intertidal species are particularly

40 susceptible to fluctuations in aerial conditions and many are considered indicators of

41 climate change. Perna viridis is a recent invader to the United States where it fouls hard

42 substrates and soft sediment habitats. During winter 2007-2008, a mortality event was

43 observed for $P$. viridis across Tampa Bay, Florida. This mortality event coincided with

44 extreme weather conditions when air temperatures dropped below $2^{\circ} \mathrm{C}$ for a period of 6

45 hours during low water. The minimum air temperature recorded was $0.53^{\circ} \mathrm{C}$. During this

46 period water temperature remained relatively constant $\left(\sim 20^{\circ} \mathrm{C}\right)$. We provide strong

47 evidence supporting the hypothesis that thermal stress relating to exposure to cold air

48 temperatures during emersion was the primary factor underpinning the mortality event.

49 Similar mortality events occurred in 2009 and 2010, also coinciding with prolonged

50 exposure to low air temperatures.

52 In the short term, weather may be responsible for the temporary trimming back of

53 populations at the edge of their geographic but in the longer-term, it is expected that

54 climate warming will trigger the poleward movement of both native and non-native

55 species potentially facilitating biotic homogenisation of marine communities. The

56 challenge now is to devise adaptive management strategies in order to mitigate any

57 potential negative impacts to native biodiversity. 


\section{Introduction}

60 Global climate change and invasive non-native species represent two of the most serious

61 global threats to biodiversity and the environment (Stachowicz et al., 2002; Ward and

62 Masters 2007). Biological communities are responding to global climate change through

63 poleward shifts in distribution, and changes in abundance and phenology (Sims et al.,

64 2004; Mieszkowska et al., 2005; Hiddink and ter Hofstede, 2008; Moore et al., 2010;

65 Aprahamian et al., 2010; Wethey et al., 2011). Changes in distribution and associated

66 species interactions have the potential to greatly affect the structure and functioning of

67 communities (Moore et al., 2007; Firth et al., 2009). Climate change not only facilitates a

68 shift in the distribution of indigenous species but also the establishment and extension in

69 range of non-indigenous species (Stachowicz et al., 2002; Sorte et al., 2010a, b).

71 Furthermore, global climate change is expected to lead to an increase in the frequency

72 and magnitude of extreme weather events (IPCC, 2007). Fluctuation in temperature is

73 well documented as a driver of mortality in many marine species at temperate and

74 subpolar latitudes (Orton, 1933; Harley et al., 2006; Coma et al., 2009; Firth and

75 Williams, 2009; Sorte et al., 2011) and disease outbreak is often associated with

76 increased temperatures (Harvell et al., 1999; Bruno et al., 2007). Conversely, mortality

77 events driven by cold thermal stress have received less attention, particularly at

78 subtropical and tropical latitudes; with the majority of studies describing effects on coral

79 reefs in tropical waters (e.g. Laboy-Nieves et al., 2001; Saxby et al., 2003).

81 The record-breaking cold temperatures experienced in the Northern Hemisphere during

82 winter 2009/2010 were a result of extremely negative values of the North Atlantic

83 Oscillation (NAO) index (Wang et al., 2010). If the trend of increased frequency of

84 NAO-negative years continues, it is predicted that more frequent cold outbreaks are

85 likely in the future (Wang et al., 2010).

87 Prolonged cold outbreaks can have a severe detrimental effect on marine organisms, 88 particularly those occurring in the intertidal zone (Crisp 1964; Wethey et al., 2011).

89 Organisms living in the intertidal zone are of marine origin but experience terrestrial 
90 conditions daily during low tide. The upper distributional limits of intertidal organisms

91 are set by physical factors such as thermal and desiccation stress (Connell, 1972; Somero,

92 2002; Harley et al., 2006; Hawkins et al., 2008, 2009). This vulnerability to terrestrial

93 conditions infers that variations in climatic conditions are likely to elicit strong responses

94 in intertidal organisms and result in changes in distribution and community structure and

95 functioning (Fields et al., 1993; Lubchenco et al., 1993; Helmuth et al., 2006). The

96 responses of intertidal organisms to environmental conditions has allowed for them to

97 serve as proxies for changes occurring offshore (Mieszkowska et al., 2005).

99 The Asian green mussel, Perna viridis, is native to the tropical Indo-Pacific region, 100 primarily distributed along the Indian and southeast Asian coasts (Siddall, 1980; Vakily,

101 1989; Rajagopal et al., 2006). This species was first recorded in North America in 1999,

102 where it was found to be fouling the intake tunnels of a power station in Tampa Bay,

103 Florida (Benson et al., 2001), and is thought to have been introduced through ballast

104 water exchange (Power et al., 2004). The mussel has since spread to both the Gulf and

105 Atlantic coasts of Florida (Ingrao et al., 2001; Baker et al., 2007) occurring as far

106 eastwards as Panama City on the Florida Panhandle and north towards Georgia (Power et

107 al., 2004). A recent survey indicated that individuals have extended as far north as South

108 Carolina (Benson, 2010). The mussel is found attached to the many forms of hard

109 structure introduced by man (pilings, docks, bridge supports) as the natural coastline is

110 characterized by soft sediments. It occurs on these hard substrates both in the intertidal

111 and in the subtidal zones, where it is also known to occur on soft sediments and among

112 sea grass beds (Bell, pers. obs). Little is known about the impact of this species on native

113 biodiversity but as its range expands, new interactions with indigenous species are likely

114 to occur. For example, one observation suggests that $P$. viridis may out-compete the

115 commercially important native eastern oyster, Crassostrea virginica. During a survey of

$116 P$. viridis in Tampa Bay, Baker et al., (2007) observed a layer of dead C. virginica shells

117 covered by $P$. viridis. Where living $C$. virginica was found, individuals were limited to

118 the upper few centimetres of the intertidal, above $P$. viridis. Subsequent to a $P$. viridis

119 winter die-off in January 2003, Baker et al., (2007) were unable to find any living $C$.

120 virginica in the area previously occupied by $P$. viridis. It is well documented that 
121 mussels provide refuge and habitat for a wide variety of associated organisms (Seed,

122 1996) and that this function can vary with size of mussels (O'Connor and Crowe, 2007).

123 Little is known about the biodiversity associated with $P$. viridis patches, but due to

124 differences in size of individuals and patch complexity between oysters and mussels, it is

125 likely that expansion of the green mussel will have potentially long-term effects on

126 diversity of epibiota and mobile fauna.

128 While ecological information on the green mussel is quite limited after its spread to

129 Tampa Bay, field observations at a small number of locations suggested that cold winter

130 temperatures might be responsible for an observed temporary disappearance of $P$. viridis

131 populations from the intertidal zone in Tampa Bay (Baker et al., 2007). Here, we examine

132 data from a bay-wide survey of mussels to evaluate whether patterns of mussel

133 distribution and abundance are suggestive of a large-scale mortality event. Likewise, by

134 following mussels over a smaller number of sites for a 2-year period, we determine

135 whether mortality events can potentially happen whenever acute cold weather events

136 occur in Tampa Bay.

\section{2. Materials \& methods}

\subsection{Study sites}

141 Tampa Bay, Florida exhibits an increasing salinity gradient from north to south (Barber et

142 al., 2005). Nine survey locations were selected across a wide area of Tampa Bay, for

143 which salinity data were available for the 12 months prior to December 2007, and

144 comprised hard substrata (bridge pilings, pier pilings or pontoons) for attachment of

145 mussels. Locations (Figure 1) that were surveyed were Safety Harbor Pier; McKay Bay

146 Bridge; Ballast Point Pier; Gandy Bridge; Davis Islands Slipway; Fantasy Island Pier;

147 Picnic Island Pier; Sunshine Skyway Bridge and Fort De Soto Slipway.

149 At each location, 12 quadrats $(20 \times 20 \mathrm{~cm})$ were placed $1 \mathrm{~m}$ below the mean high water

150 mark on all orientations of pilings or just below the water mark on pontoons. All mussels

151 within quadrats were destructively sampled and measured (anterior to posterior) to the 
152 nearest $1 \mathrm{~mm}$ in the laboratory. The survey was initially carried out between $10-14^{\text {th }}$

153 December 2007 in order to establish baseline information on the distribution and

154 abundance of $P$. viridis in Tampa Bay. On a subsequent visit to Davis Islands in January

155 2008, it was observed that all of the mussels at the study site and surrounding area were

156 dead. Following this, a complete resurvey of all locations was carried out from $18-20^{\text {th }}$

157 February 2008 when it was suspected that a mortality event had occurred across Tampa

158 Bay. All locations were again resurveyed from 5-6 ${ }^{\text {th }}$ May 2008. Individual mussels were

159 categorised into size classes based on their antero-postero length: small (<49 $\mathrm{mm})$;

160 medium $(50-99 \mathrm{~mm})$; and large (>50 mm). In addition, the presence/absence of mussels

161 was noted in the intertidal zone in summer and winter months at three sites: Courtney

162 Campbell Causeway (near Safety Harbor), Gandy Bridge and Sunshine Skyway Bridge

163 from 2008-2010.

\subsection{Physico-chemical parameters}

167 The Environmental Protection Commission of Hillsborough County collected monthly

168 salinity (ppt) measurements by placing a probe just below the surface of the water at all

169 sampling locations across Tampa Bay between January-December 2007. Additionally,

170 data on air and water temperature on a 6 hour basis was obtained from a meteorological

171 station near St. Petersburg Florida and supplied by TB-PORTS (Tampa Bay Physical

172 Oceanographic Real-Time System) for all dates from 2007-2010 (Table 1).

1742.3 Analyses

175 Analysis of variance (ANOVA) was used to test the a posteriori hypothesis that a

176 mortality event occurred in Tampa Bay using density of mussels as the dependent

177 variable. Two-factor ANOVA was performed using the factors: survey (3 levels, random,

178 orthogonal); and location (9 levels, random, orthogonal) with 12 replicates. GMAV®

179 version 5 for Windows was used for computations (Underwood and Chapman, 1998).

180 Cochran's test was used to test for heterogeneity of variances and Student-Newman-

181 Keuls (SNK) procedure was used to make post hoc comparisons among levels of 
182 significant terms. Variances were heterogeneous, but it was not possible to transform the 183 data.

185 One-factor ANOVA was used to test differences in salinity between sites using data from 186 each month as a replicate (January-December 2007, $\mathrm{n}=12$ ). The relationship between 187 mussel abundance and salinity was tested using least squares linear regression analysis 188 (Sokal and Rohlf 2003).

190 3. Results

1913.1 Mussel survey

192324 quadrats were sampled comprising a total of 1452 mussels. Total mussel abundance

193 (across 3 surveys) was highest at Safety Harbor (376) and lowest at Sunshine Skyway

194 Bridge (23). Mean density per quadrat during the first sampling period $\left(10-14^{\text {th }}\right.$

195 December 2007) was also highest at Safety Harbor (31.3), then Ballast Point (24.6) and

196 lowest at Sunshine Skyway (1.91) and Fort De Soto (1.0) with other locations

197 characterised by populations of intermediate density (Figure 2).

199 A bay-wide mortality event of Perna viridis occurred between December 2007 and May

2002008 (Figure 2). On the second sampling period in February 2008, live mussels were only 201 recorded at Gandy Bridge, Picnic Island and Fort De Soto (Table 2, Figure 2). At

202 locations where no live mussels were observed within the quadrats, a broad visual search 203 was done of the sampling site for any live mussels but none were recorded. Dead mussel 204 shells were observed attached to the substrate or on the sea-bottom at many of the 205 locations, indicating recent mortality. On the third sampling period (May 2008), 206 populations at both Gandy Bridge and Picnic Island had also decreased to zero with Fort 207 De Soto being the only location where any live mussels were recorded (Figure 2).

209 Surveys in 2009-2010 also indicated the disappearance of mussels after unusually cold 210 temperatures. While mussels were present in October 2008 and 2009, none were found 211 in January 2009 or 2010 on structures in the intertidal zone at the study sites. 
214 The mean daily variation in air and water temperature for St. Petersburg, located within

215 the middle reaches of Tampa Bay was recorded for the period between 11/12/2007 and

$21619 / 02 / 2008$ (Figure 3). Water temperature was relatively constant, remaining above $20^{\circ} \mathrm{C}$

217 (20-25) for the majority of the period. Water temperature twice dipped slightly below

$21820^{\circ} \mathrm{C}(17-19)$ between $4-11^{\text {th }}$ January and again between $16^{\text {th }}$ January and $3^{\text {rd }}$ February.

220 Air temperature was generally a few degrees cooler than water temperature (Figure 3),

221 but a major drop in air temperature occurred between 2-4 January 2008 when

222 temperatures remained below $15^{\circ} \mathrm{C}$ for 64 hours. During this 3-day period, the

223 temperature dropped again and mussels were exposed to severely cold air temperatures

$224\left(<2^{\circ} \mathrm{C}\right)$ for 6 hours when a minimum temperature of $0.53^{\circ} \mathrm{C}$ was recorded at 12:00 during

225 low water (Figure 4).

227 Winter temperatures from 2009-2010 again showed a series of dates when air

228 temperatures were less than $15^{\circ} \mathrm{C}$. As in January 2008, air temperatures declined to near

$2290^{\circ} \mathrm{C}$ once and remained lower than $15^{\circ} \mathrm{C}$ for at least 3 days (Table 1 ).

\subsection{Mussel abundance in relation to salinity}

232 To characterise the relationship between mussel abundance and salinity, mussel

233 abundance data collected during the $1^{\text {st }}$ survey in December 2007 were considered in

234 relation to the salinity data collected over the preceding 12 months between January-

235 December 2007.

237 ANOVA revealed significant differences between locations for salinity (Table 3). Post-

238 hoc SNK procedures revealed three distinct groupings: Safety Harbor was grouped on its

239 own with the lowest salinity; in contrast, Fort De Soto and Sunshine Skyway clustered

240 together with the highest salinity. The rest of the locations formed a group representing

241 intermediate salinity (Table 3). 
243 There was a strong negative relationship between mussel abundance and salinity (Figure

244 5). The greatest densities were found at the location with lowest salinity (Safety Harbor)

245 and the lowest densities were found at the locations with the highest salinities (Fort De

246 Soto and Sunshine Skyway) (Figure 5).

248 Population structure showed greater heterogeneity (i.e., characterised by mussels of

249 different sizes), at locations of intermediate salinity compared to sites of highest/lowest

250 salinity (Figure 6). Moreover, at locations characterised by extreme salinities (i.e. Safety

251 Harbor, Sunshine Skyway and Fort De Soto), no individuals in the larger size class were

252 found during the first survey in December 2007.

\section{4. Discussion}

256 We provide strong evidence supporting the hypothesis that thermal stress related to 257 exposure to cold air temperatures during emersion was the primary factor underpinning

258 the mortality event for mussels occupying intertidal substrata across sites in Tampa Bay

259 in 2008. Our observations indicate that mussels recruit back to the intertidal in early 260 summer. Importantly, in the two years subsequent to our initial bay-wide survey, we

261 found that the winter die-off was repeated at three sites where mussels were abundant in 262 the 2007 survey and extreme cold air temperatures were reported during the winters of 263 2008/2009 and 2009/2010. These events do not appear to be unique as a similar mortality

264 event occurred in the mussel populations on the northeast coast of Florida in 2007/2008 265 (M. Gilg, pers. comm.). Perna viridis is also known to experience winter die-offs in 266 Japan (Umemori and Horikoshi, 1991; Kazuhiro and Sekiguchi, 2000; Zvyagintsev, 267 2003) where it is also considered an invasive species.

269 During 2007/2008 an extreme weather event occurred in Tampa Bay when air 270 temperatures dropped to near freezing for a period of 6 hours during low water.

271 Subsequent to this cold snap, water temperatures dipped slightly but it is unlikely that this

272 slight drop in water temperature led to the bay-wide mortality event observed in $P$.

273 viridis. A similar pattern was true for air and water temperatures from 2008-2010. It is 
274 extremely likely that the prolonged exposure to low air temperatures caused the mortality

275 events for $P$. viridis across Tampa Bay. Although not tested experimentally during the

276 present study, previous investigations have found that cold water temperature causes

277 mortality of $P$. viridis (Sivalingam, 1977; Urian et al., 2010). Little work has been carried

278 out on the effects of cold air temperatures on $P$. viridis, but a recent laboratory study

279 found that the mortality was significantly higher in mussels exposed to cold air

280 temperatures $\leq 14^{\circ} \mathrm{C}$ and that smaller individuals were less tolerant of changes in air

281 temperature than larger ones (Urian et al., 2010).

283 Thermal stress is widely cited as the dominant physical stress in intertidal habitats

284 (Garrity, 1984; Helmuth and Hofmann, 2001) and is reported to cause mortality events on

285 both temperate (Orton, 1933; Lewis, 1954; Harley et al., 2006) and tropical shores

286 (Williams and Morritt, 1995; Chan et al., 2006; Firth and Williams, 2009). Many studies

287 focus on the effects of warm thermal stress on the physiological and behavioural

288 responses of organisms (Somero, 2002; Jones et al., 2009; Denny et al., 2011; Sorte et al.,

289 2011) while the effects of cold thermal stress are often neglected, particularly at lower

290 latitudes (but see Urian et al., 2010). Furthermore, despite many intertidal organisms

291 being exposed to aerial conditions during low water, less attention has been directed at

292 assessing the effects of extreme air temperatures in comparison to extreme water

293 temperatures. This focus is perhaps surprising as larger fluctuations in temperature are

294 more likely to occur in aerial environments than aquatic environments due to the

295 buffering capacity of water (Marshall and Plumb, 2008). In a subtropical setting such as

296 described here, low aerial temperatures may be an important mechanism by which

297 mussels are prevented from excluding other fouling organisms, such as oysters and

298 barnacles.

300 Two of the predictions accompanying discussions of global climate change are (1) a rise

301 in the mean sea surface temperature globally and (2) an increase in the occurrence,

302 intensity and magnitude of extreme weather events (IPCC, 2007). Stachowicz et al.,

303 (2002) proposed that changing maximum and minimum temperatures rather than shifts in

304 annual means could account for the greatest impacts of climate change on marine 
communities. Our findings on the green mussel provide support for this proposal. Future

306 studies on changes in community assemblages that follow assemblages across years both

307 with and without extreme weather events are necessary.

309 It is well documented that climate warming on the scale of decades can alter the

310 composition of marine communities by facilitating the poleward spread of warm-adapted

311 species (Southward et al., 1995; Sagarin et al., 1999; Stachowicz et al., 2002;

312 Mieszkowska et al., 2005). Climate is typically defined as the mean of weather over a

313 large temporal scale (>30 years) (Helmuth et al., 2006). Specifically, Stenseth et al.,

314 (2003) defined weather as the fluctuation in short-term localised atmospheric conditions

315 which encompass air temperature, solar radiation, cloud cover, precipitation, and wind.

316 Recently, there has been a surge of interest on the effects of multiple environmental

317 stressors (Atalah and Crowe, 2010; Crain, 2008; Firth and Williams, 2009; Fitch and

318 Crowe, 2011) and extreme weather events (Harley et al., 2006; Hughes et al., 2009; Sorte

319 et al., 2010a,b; Wethey et al., 2011) on marine communities and increasingly, results

320 from field studies appear to justify such an emphasis.

322 For example in the United Kingdom, the extremely cold winter of 1962/1963 lasted from

323 late December 1962 through to early March 1963. During this time the mean air

324 temperatures ranged between $-3.2^{\circ} \mathrm{C}$ and $0.2^{\circ} \mathrm{C}$ (Crisp, 1964). As a result of the

325 prolonged cold temperatures, a contraction of the northern range edge of many southern

326 warm-adapted species was recorded, particularly around North Wales (Crisp, 1964). With

327 the continuing trend in climate warming, some of these species (e.g. Sabellaria alveolata,

328 Osilinus lineatus) are now beginning to recolonise locations where they previously

329 occurred (Mieszkowska et al., 2005, 2007; Hawkins pers. comm.). These recolonisations

330 have implications for community structure and functioning particularly when the species

331 involved are keystone species or provide habitat for other species (e.g. mussels, oysters:

332 see Hawkins et al., 2009).

334 The results of the present study suggest that physiological stress driven by extreme

335 weather may be responsible for limiting the invasion success of the green mussel in a 
336 subtropical area. The blue mussel, Mytilus galloprovincialis is an invasive species on the

337 California coast. Lockwood and Somero (2011) discuss how physical factors, such as

338 temperature, could be limiting its northward spread in California, while simultaneously

339 facilitating its competitive ability.

341 The unusually cold weather experienced in south Florida in January 2010 also resulted in

342 the mortality of the invasive Burmese Python (Python molurus bivattus) in Everglades

343 National Park (Mazzotti et al., 2010). Similarly, the cold winter in 2009-2010 had a

344 significant impact on intertidal marine fauna in northern Europe. Wethey et al., (2011)

345 found that southern warm-adapted (native) barnacle species (Chthamalus) suffered

346 recruitment failure, but no adult mortality in France.

348 In the short term, weather may be responsible for the temporary retreat of a population's 349 distribution at the edge of its geographic range (Crisp, 1964; Baker et al., 2007; Urian et 350 al., 2010). In the longer-term, it is expected that climate warming will facilitate both the 351 poleward movement of native species (Mieszkowska et al., 2005; Hiddink and ter 352 Hofstede, 2008) and the spread of non-indigenous species to new locations (Stachowicz 353 et al., 2002; Sorte et al., 2010a; Sorte et al., 2010b). This interaction between global

354 climate change and human-induced biological invasions may ultimately lead to biotic 355 homogenisation - the process of gradual replacement of native communities by locally 356 expanding non-native species (Olden et al., 2004). The challenge now is to forecast when 357 and where these changes are likely to occur and devise adaptive management strategies in 358 order to mitigate any potential negative impacts to native biodiversity.

\section{Acknowledgements}

362 We thank D. Karlen of the Environmental Protection Commission of Hillsborough

363 County for kindly providing salinity data. We are also very grateful to M. Middlebrooks,

364 H. Custin and K. Roberts for their assistance with laboratory and fieldwork. We also wish

365 to thank two anonymous reviewers for comments on earlier drafts of this manuscript. 
369 Table 1 . Summary of minimum air and corresponding water temperatures $\left({ }^{\circ} \mathrm{C}\right)$ from

370 PORTS for St Petersburg, Florida on dates for which lowest temperatures of the month

371 are recorded or for those dates when air temperature was $<15^{\circ} \mathrm{C}$. Duration (hours) when

372 air temperature subsequent to date reported was continuously less than $15^{\circ} \mathrm{C}$ is also noted.

\begin{tabular}{|c|c|c|c|}
\hline Date & $\begin{array}{c}\text { Low air temperature } \\
\left({ }^{\mathbf{}} \mathbf{C}\right)\end{array}$ & $\begin{array}{c}\text { Low water temperature } \\
\left({ }^{\circ} \mathbf{C}\right)\end{array}$ & $\begin{array}{c}\text { Duration } \\
(\text { hours })\end{array}$ \\
\hline $17 / 12 / 2007$ & 6 & 21 & 18 \\
\hline $04 / 01 / 2008$ & 1 & 18 & 64 \\
\hline $15 / 02 / 2008$ & 7 & 21 & 6 \\
\hline $28 / 11 / 2008$ & 7 & 20 & 6 \\
\hline $20 / 01 / 2009$ & 4 & 18 & 36 \\
\hline $04 / 02 / 2009$ & 3 & 17 & 18 \\
\hline $05 / 12 / 2009$ & 9 & 21 & 6 \\
\hline $09 / 12 / 2009$ & 9 & 20 & 24 \\
\hline $28 / 12 / 2009$ & 9 & 19 & 12 \\
\hline $10 / 01 / 2010$ & 0 & 12 & 120 \\
\hline $14 / 02 / 2010$ & 8 & 17 & 6 \\
\hline
\end{tabular}

377 Table 2. Analysis of variance (ANOVA) to assess differences in $P$. viridis density at 9

378 locations in Tampa Bay in December 2007, February 2008 and May 2008, $(* * * *=$ $379 \mathrm{P}<0.001)$.

\begin{tabular}{|l|r|r|l|}
\hline Source & \multicolumn{1}{l|}{ df } & MS & $\boldsymbol{F}$ \\
\hline Survey & 2 & 5450.73 & $13.34^{* * *}$ \\
\hline Location & 8 & 387.78 & 0.95 \\
\hline Survey $\times$ Location & 16 & 408.51 & $8.29^{* * *}$ \\
\hline RES & 297 & 49.28 & \\
\hline
\end{tabular}


385 Table 3. Analyses of variance (ANOVA) to test the differences in sea surface temperature $386\left({ }^{\circ} \mathrm{C}\right)$ and salinity (ppt) between locations. $(* *=\mathrm{P}<0.01 ; * * *=\mathrm{P}<0.001)$.

387

\begin{tabular}{|l|l|l|l|}
\hline & & \multicolumn{2}{|l|}{ Salinity } \\
\hline Source & df & MS & F \\
\hline Location & 8 & 79.43 & $27.72 * * *$ \\
\hline Total & 99 & & \\
\hline Cochrans $C$ & & P $<0.05$ & \\
\hline Transformation & & None & \\
\hline & & & \\
\hline SNK tests & \multicolumn{2}{|l|}{ SH< MB=BP=GB=DI=FI=PI=SS $<<\mathrm{FS}$} \\
\hline
\end{tabular}

388

389

390 
393 Figure 1. Map of survey locations in Tampa Bay. SH = Safety Harbor; $\mathrm{MB}=$ McKay

394 Bay; BP = Ballast Point; GB = Gandy Bridge; DI = Davis Islands; FI = Fantasy Island; PI

395 = Picnic Island; SS = Sunshine Skyway; FS = Fort De Soto.

397 Figure 2. Mean abundance of Perna viridis in quadrats $\left(0.04 \mathrm{~m}^{2}\right)$ at each location: Safety

398 Harbor; McKay Bay; Ballast Point; Gandy Bridge; Davis Islands; Fantasy Island; Picnic

399 Island; Sunshine Skyway; Fort De Soto

Figure 3. Mean daily air and water temperature $\left({ }^{\circ} \mathrm{C}\right)$ measured at St. Petersburg, Florida during the period of the study (11/12/2007 to 19/02/2008). Data obtained from

403 http://tidesandcurrents.noaa.gov

405 Figure 4. Hourly air and water temperatures $\left({ }^{\circ} \mathrm{C}\right)$ and water height (m) relative to MLW 406 measured at St. Petersburg, Florida during the period of cold weather between $2^{\text {nd }}$ and $4^{\text {th }}$

407 February 2008. Arrow indicates low water (4.13 m below MTL) coinciding with

408 extremely cold air temperature $\left(0.5^{\circ} \mathrm{C}\right)$. Data obtained from

409 http://tidesandcurrents.noaa.gov

411 Figure 5. The relationship between mean abundance of $P$. viridis per quadrat and salinity 412 (ppt). Only data from December 2007 survey is used here. $(\mathrm{F}=44.46, \mathrm{P}<0.001)$.

414 Figure 6. Size-frequency distributions of $P$. viridis across locations in Tampa Bay.

415 Locations are grouped in order of increasing salinity from left to right. $\mathrm{SH}=$ Safety

416 Harbor; MB=McKay Bay; BP = Ballast Point; Gandy Bridge; $\mathrm{DI}=$ Davis Islands; FI =

417 Fantasy Island; PI = Picnic Island; SS = Sunshine Skyway; FS = Fort De Soto. 
Aprahamian, M., Aprahamian, C. D. and Knights, A. M., 2010. Climate change and the 'green' energy paradox: its consequences for Alosa fallax from the River Severn, England. J. Fish. Biol. 77, 1912-1930.

Atalah, J., and Crowe, T. P., 2010. Combined effects of nutrient enrichment, sedimentation and grazer loss on rock pool assemblages. J. Exp. Mar. Biol. Ecol. 388, 51-57.

Baker, P., Fajans, J. S., Arnold, W. S., Ingrao, D. A., Marelli, D. C., and Baker, S. M., 2007. Range and dispersal of a tropical marine invader, the Asian green mussel, Perna viridis, in subtropical waters of the southeastern United States. J. Shell. Res. 26, 1-11.

Barber, B. J., Fajans, J. S., Baker, S. M., Baker, P., 2005. Gametogenesis in the nonnative green mussel, Perna viridis, and the native scorched mussel, Brachiodontes exustus in Tampa Bay, Florida. J. Shell. Res. 24, 1087-1095

Benson, A., Marelli, D. C., Frischer, M. E., Danforth, J. M., and Williams, J. D., 2001. Establishment of the green mussel, Perna viridis (Linnaeus 1758), (Mollusca: Mytilidae) on the west coast of Florida. J. Shell. Res. 20, 21-29.

Benson, A. J., 2010. Perna viridis. USGS Nonindigenous Aquatic Species Database, Gainesville, FL. http://nas.er.usgs.gov/queries/factsheet.aspx?SpeciesID=110

Bruno, J. F., Selig, E. R., Casey, K. S., Page, C. A., Willis, B. L., Harvell, C. D., Sweatman, H., et al. 2007. Thermal stress and coral cover as drivers of coral disease outbreaks. PLoS Biol. 5, e124.

Chan, B. K. K., Morritt, D., De Pirro, M., Leung, K. M. Y., and Williams, G. A., 2006. Summer mortality: effects on the distribution and abundance of the acorn barnacle Tetraclita japonica on tropical shores. Mar. Ecol. Prog. Ser. 328, 195-204.

Coma, R., Ribes, M., Serrano, E., Jiménez, E., Salat, J., and Pascual, J., 2009. Global warming-enhanced stratification and mass mortality events in the Mediterranean Proc. Nat. Acad. Sci. USA. 106, 6176-6181.

Connell, J. H., 1972. Community interactions on marine rocky intertidal shores. Ann. Rev. Ecol. Syst. 3, 169-192. 
Crain, C. M., 2008. Interactions between marsh plant species vary in direction and strength depending on environmental and consumer context. J. Ecol. 96, 166-173.

453 Crisp, D. J., 1964. The effects of the winter of 1962/63 on the British marine fauna. J.

454 Anim. Ecol. 33, 165-210.

455 Denny, M. W., Wesley Dowd, W., Bilir, L., and Mach K. J., 2011. Spreading the risk: Small-scale body temperature variation among intertidal organisms and its implications for species persistence. J. Exp. Mar. Biol. Ecol. This issue

Fields, P. A., Graham, J. B., Rosenblatt, R. H., and Somero, G. N., 1993. Effects of expected global climate change on marine faunas. Trend. Ecol. Evol. 8, 361-367.

Firth, L. B., Crowe, T. P., Moore, P., Thompson, R. C., and Hawkins, S. J., 2009. Predicting impacts of climate-induced range expansion: an experimental framework and a test involving key grazers on temperate rocky shores. Glob. Chan. Biol. 15, 1413-1422.

Firth, L. B., and Williams, G. A., 2009. The influence of multiple environmental stressors on the limpet Cellana toreuma during the summer monsoon season in Hong Kong. J. Exp. Mar. Biol. Ecol. 375, 70-75.

Fitch, J. E., and Crowe, T. P. 2011., Combined effects of temperature, inorganic nutrients and organic matter on ecosystem processes in intertidal sedimentary assemblages. J. Exp. Mar. Biol. Ecol. This issue

Garrity, S. D. 1984., Some adaptations of gastropods to physical stress on a tropical rocky shore. Ecology. 65, 559-574.

Harley, C. D. G., Hughes, A. R., Hultgren, K. M., Miner, B. G., Sorte, C. J. B., Thorner, C. S., Rodriguez, L. F., et al. 2006. The impacts of climate change on marine systems. Ecol. Lett. 9, 228-241.

Harvell, C. D., Kim, K., Burkholder, J. M., Colwell, R. R., Epstein, P. R., Grimes, D. J., Hofmann, E. E., et al. 1999. Emerging marine diseases - climate links and anthropogenic factors. Science. 285, 1505-1510.

Hawkins, S.J., Moore, P.J., Burrows, M.T., Poloczanska, E., Mieszkowska, N., Herbert, R.J.H., Jenkins, S.R., Thompson, R.C., Genner, M.J., Southward, A.J., 2008. Complex interactions in a rapidly changing world: responses of rocky shore communities to recent climate change. Clim. Res. 37, 123-133. 
Hawkins, S., Sugden, H., Mieszkowska, N., Moore, P., Poloczanska, E., Leaper, R., Herbert, R., Genner, M., Moschella, P., Thompson, R., Jenkins, S., Southward, A., Burrows, M., 2009. Consequences of climate-driven biodiversity changes for ecosystem functioning of North European rocky shores. Mar. Ecol. Prog. Ser. 396, 245-259.

Helmuth, B., and Hofmann, G. E., 2001. Microhabitats, thermal heterogeneity, and patterns of physiological stress in the rocky intertidal zone. Biol. Bull. 201, 374384.

Helmuth, B., Mieszkowska, N., Moore, P., and Hawkins, S. J., 2006. Living on the edge of two changing worlds: forecasting the responses of rocky intertidal ecosystems to climate change. Ann. Rev. Ecol. Evol. Syst. 37, 373-404.

Hiddink, J. G., and ter Hofstede, R., 2008. Climate induced increases in species richness of marine fishes. Glob. Chan. Biol. 14, 453-460.

Hughes, C., Richardson, C. A., Luckenbach, M., and Seed, R., 2009. Difficulties in separating hurricane induced effects from natural benthic succession: Hurricane Isabel, a case study from Eastern Virginia, USA. Est. Coast. Shel. Sci. 85, 377 386.

Ingrao, D. A., Mikkelsen, P. M., and Hicks, D. W., 2001. Another introduced marine mollusk in the Gulf of Mexico: the Indo-Pacific green mussel, Perna viridis, in Tampa Bay, Florida. J. Shell. Res. 20, 13-19.

IPCC, 2007. Climate Change 2007: The Physical Science Basis - Summary for Policymakers. Contribution of working group I to the fourth assessment report of the Intergovernmental Panel on Climate Change. 21 pp.

Jones, S. J., Mieszkowska, N., and Wethey, D. S., 2009. Linking thermal tolerances and biogeography: Mytilus edulis (L.) at its southern limit on the east coast of the United States. Biol. Bull. 217, 73-85.

Kazuhiro, H., and Sekiguchi, H., 2000. Perna mussels introduced into Ise and Mikawa Bays, Central Japan. Sessile Organisms. 17, 1-11. [in Japanese with English summary]. 
511 Laboy-Nieves, E. N., Klein, E., Conde, J. E., Losada, F., Cruz, J. J., and Bone, D., 2001.

512 Mass mortality of tropical marine communities in Morrocoy, Venezuela. Bull.

513 Mar. Sci. 68, 163-179.

514 Lewis, J. R., 1954. Observations on a high-level population of limpets. J. Anim. Ecol. 23, $515 \quad 85-100$.

516 Lockwood, B. L., and Somero, G. N., 2011. nvasive and native blue mussels (genus

517 Mytilus) on the California coast: the role of physiology in a biological invasion. J.

$518 \quad$ Exp. Mar. Biol. Ecol. This issue

519 Lubchenco, J., Navarrete, S. A., Tissot, B. N., and Castilla, J. C., 1993. Possible

520 ecological responses to global climate change: nearshore benthic biota of Change, pp. 147-166. Ed. by H. A. Mooney, E. R. Fuentes, and B. I. Kronberg. Academic Press, New York.

Marshall, J., and Plumb, R. A. , 2008. Atmosphere, ocean, and climate dynamics: an introductory text. Elsevier Academic Press, Burlington, USA.

Mazzotti, F. J., Cherkiss, M. S., Hart, K. M., Snow, R. W., Rochford, M. R., Dorcas, M. E., Reed, R. N., (in press). Cold-induced mortality of invasive burmese pythons in south Florida. Biol. Invas.

Mieszkowska, N., Leaper, R., Moore, P., Kendall, M. A., Burrows, M. T., Lear, D., Poloczanska, E., et al. 2005. Assessing and predicting the influence of climatic change using rocky shore biota. Occ. Publ. J. Mar. Biol.Ass. UK. 20, 701-752.

Mieszkowska, N., Hawkins, S. J., Burrows, M. T., Kendall, M. A., 2007. Long-term changes in the geographic distribution and population structures of Osilinus lineatus (Gastropoda: Trochidae) in Britain and Ireland. J. Mar. Biol. Ass. UK. $89,537-545$.

Moore, P., Thompson, R. C., and Hawkins, S. J., 2007. Effects of grazer identity on the probability of escapes by a canopy-forming macroalga. J. Exp. Mar. Biol. Ecol. 344, 170-180.

Moore, P. J., Thompson, R. C., and Hawkins, S. J., 2010. Phenological changes in intertidal con-specific gastropods in response to climate warming. Glob. Chan. Biol. In press. 
542 O'Connor N. E., and Crowe, T. P., 2007. Biodiversity among mussels: separating the 543 influence of sizes of mussels from the ages of patches. J. Mar. Biol. Assoc. U.K. $544 \quad 87,551-557$

545 Olden, J. D., LeRoy Poff, N., Douglas, M. R., Douglas, M. E., and Fausch, K. D., 2004.

546 Ecological and evolutionary consequences of biotic homogenization. Trend. Ecol. 547 Evol. 19, 18-24.

548 Orton, J. H., 1933. Some limiting factors in the environment of the common limpet, 549 Patella vulgata. Nature. 131, 693-694.

550 Power, A. J., Walker, R. L., Payne, K., and Hurley, D., 2004. First occurrence of the 551

Rajagopal, S., Venugopalan, V. P., Van der Velde, G., and Jenner, H. A., 2006. Greening 554 of the coasts: a review of the Perna viridis success story. Aquat. Ecol. 40, 273297.

556 Sagarin, R. D., Barry, J. P., Gilman, S. E., and Baxter, C. H., 1999. Climate related 557 change in an intertidal community over short and long time scales. Ecol. Mono. $558 \quad 69,465-490$.

559 Saxby, T., Dennison, W. C., and Hoegh-Guldberg, O., 2003. Photosynthetic responses of 560 the coral Montipora digitata to cold thermal stress. Mar. Ecol. Prog. Ser. 248, 8597.

562 Seed, R., 1996. Patterns of biodiversity in the macro-invertebrate fauna associated with mussel patches on rocky shores. J. Mar. Biol Assoc. UK. 76, 203-210

564 Siddall, S. E., 1980. A clarification of the genus Perna (Mytilidae). Bull. Mar. Sci. 30, $565 \quad 858-870$.

566 Sims, D. W., Wearmouth, V. J., Genner, M. J., Southward, A. J., and Hawkins, S. J., 567 2004. Low-temperature-driven early spawning migration of a temperate marine 568 fish. J. Anim. Ecol. 73, 333-341.

569 Sivalingam, P.M., 1977. Aquaculture of the green mussel, Mytilus viridis Linnaeus, in $570 \quad$ Malaysia. Aquaculture 4:297-312.

571 Sokal, R. R. and Rohlf, F. J., 1995. Biometry. W. H. Freeman and company, New York. 
572 Somero, G. N., 2002. Thermal physiology and vertical zonation of intertidal animals:

573 optima, limits, and costs of living. Integr. Compar. Biol. 42, 780-789.

574 Sorte, C. J. B., Fuller, A., and Bracken, M. E. S., 2010a. Impacts of a simulated heat

575 wave on composition of a marine community. Oikos, In press

576 Sorte, C. J. B., Williams, S. L., and Zerebecki, R. A. 2010b., Ocean warming increases

577 threat of invasive species in a marine fouling community. Ecology. 91, 2198-

5782204.

579 Sorte, C. J. B., Jones, S. J., and Miller, L. P., 2011. Geographic variation in temperature

580 tolerance as an indicator of potential population responses to climate change. J.

$581 \quad$ Exp. Mar. Biol. Ecol. This issue

582 Southward, A. J., Hawkins, S. J., and Burrows, M. T., 1995. Seventy years' observations

583 of changes in distribution and abundance of zooplankton and intertidal organisms

584 in the western English Channel in relation to rising sea temperature. J. Therm.

585 Biol. 20, 127-155.

586 Stachowicz, J. J., Terwin, J. R., Whitlatch, R. B., and Osman, R. W., 2002. Linking

$587 \quad$ climate change and biological invasions: Ocean warming facilitates

588 nonindigenous species invasions. Proc.Nat. Acad. Sci. USA. 99, 15497-15500.

589 Stenseth, N. C., Ottersen, G., Hurrell, J. W., Mysterud, A., Lima, M., Chan, K.-S.,

590 Yoccoz, N. G., et al. 2003. Studying climate effects on ecology through the use of

591 climate indices: the North Atlantic Oscillation, El Niño Southern Oscillation and

592 beyond Proc. R. Soc.Lond. B: Biol. Sci. 270, 2087-2096.

593 Umemori, T., and Horikoshi, M., 1991. Death and survival during winter season in

594 different populations of the green mussel, Perna viridis (Linnaeus), living in

595 different sites within a cove on the western coast of Tokyo Bay. Umi. 29, 103-107

596 [in Japanese with English summary].

597 Underwood, A. J., and Chapman, M. G., 1998. GMAV 5, Sydney, Australia: Institute of

$598 \quad$ Marine Ecology, University of Sydney, Australia.

599 Urian, A., Hatle, J., and Gilg, M., 2010. Thermal constraints for range expansion of the

600 invasive green mussel, Perna viridis, in the southeastern United States. J. Exp.

601 Zool. 313A, 1-10. 
Vakily, J. M., 1989. The biology and culture of mussels of the genus Perna. ICLARM. Studies and Reviews 17. International Center for Living Aquatic Resources Management, Manilla, Philippines, 63 pp.

Wethey, D. S., Woodin, S. A., Hilbish, T. J., Jones, S. J., Lima, F. P., 2011. Response of intertidal populations to climate: effects of extreme events versus long term change. J. Exp. Mar. Biol. Ecol. This issue

Williams, G. A., and Morritt, D. 1995. Habitat partitioning and thermal tolerance in a tropical limpet, Cellana grata. Mar. Ecol. Prog. Ser. 124, 89-103.

Zvyagintsev, A. Y., 2003. Introduction of species into the northwestern Sea of Japan and 


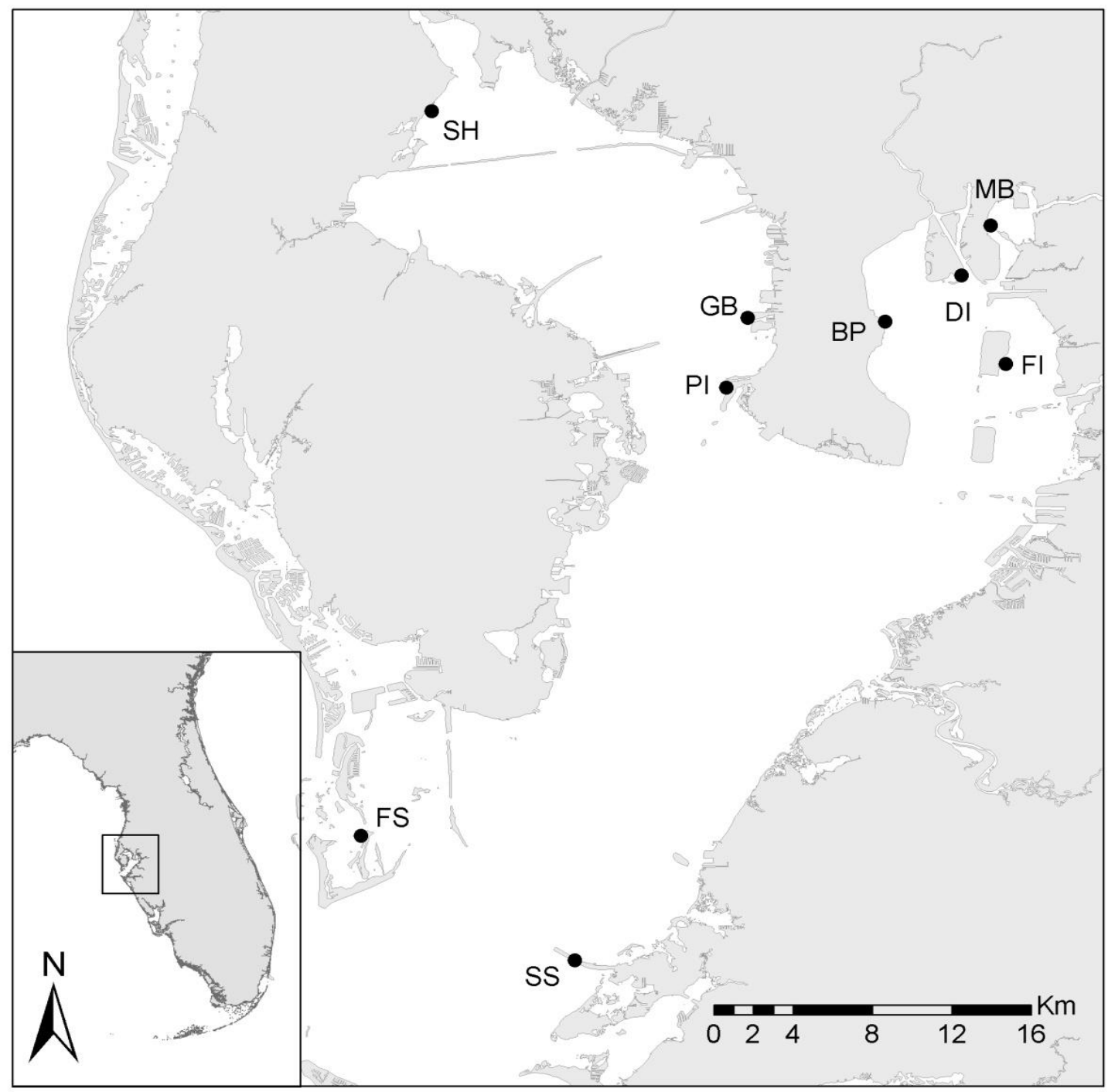

633 


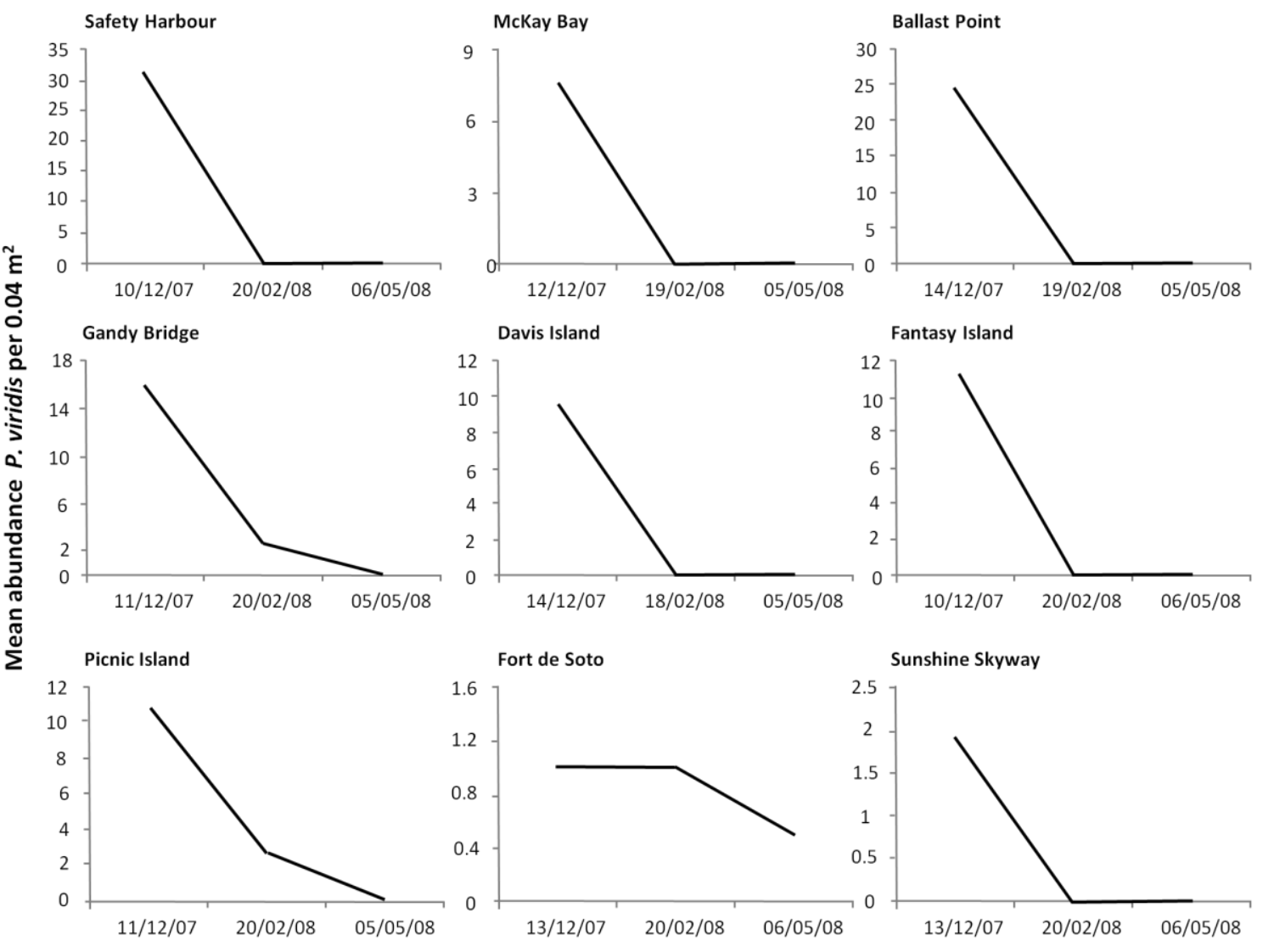

\section{Figure 2.}




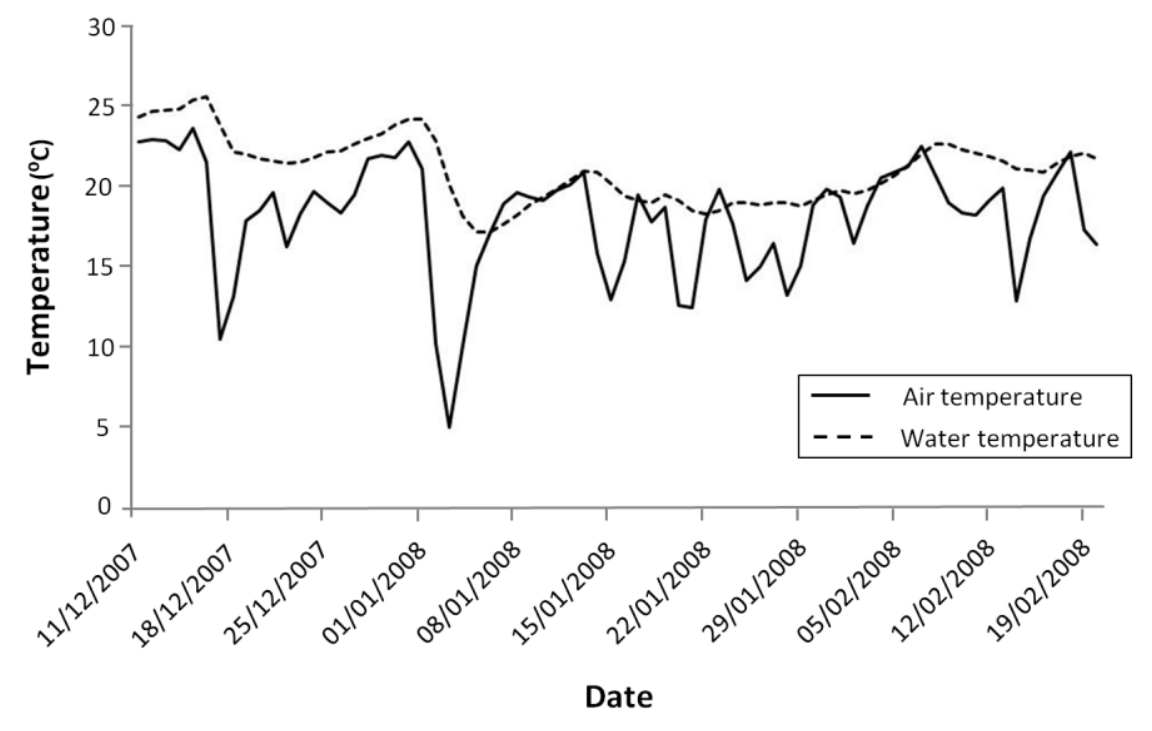

650

651

652 Figure 3.

653

654

655

656

657

658

659

660

661

662

663

664

665

666

667

668

669 


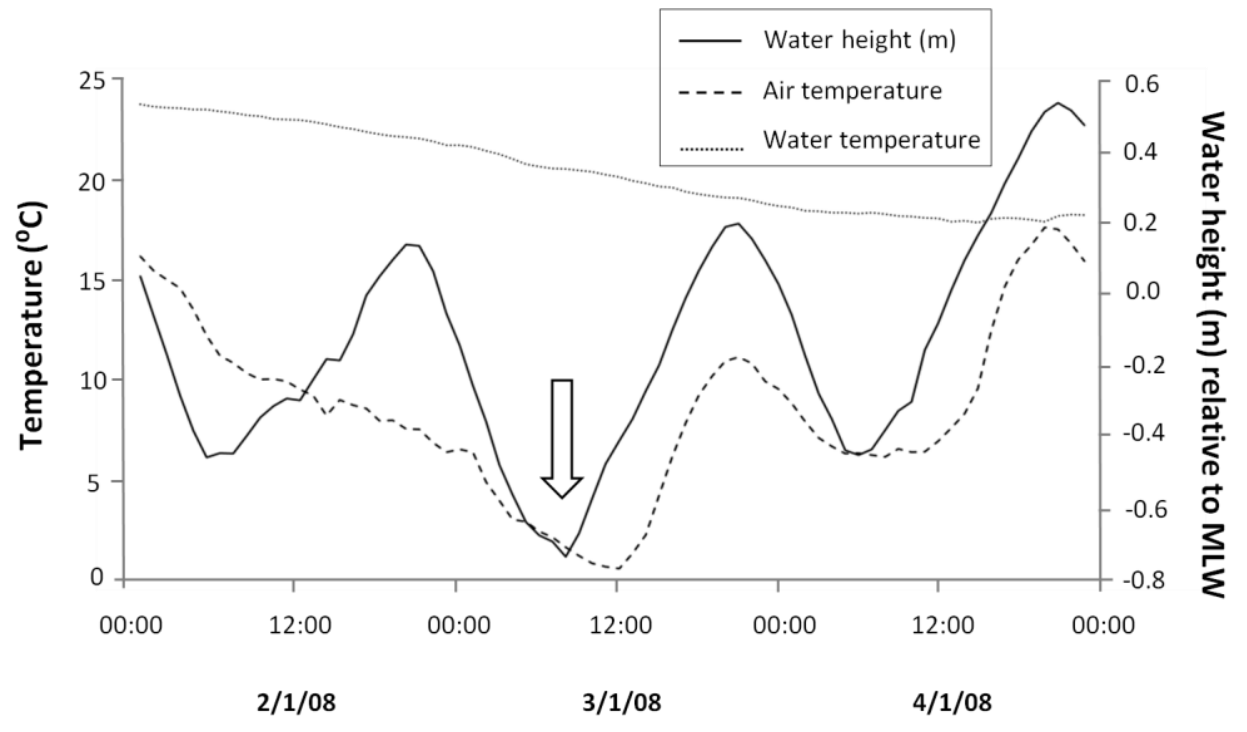

671

672 Figure 4.

673

674

675

676

677

678

679

680

681

682

683

684

685

686

687

688

689

690

691 


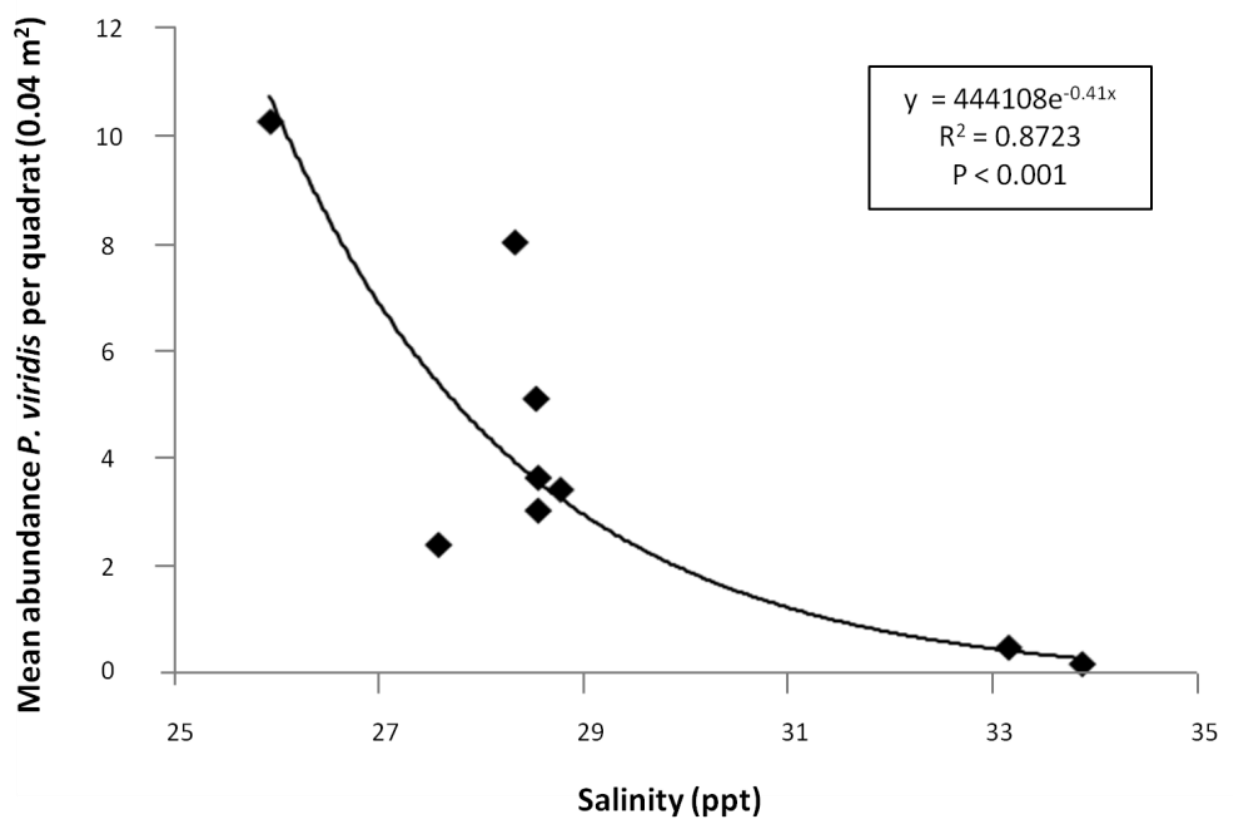

692

693

694 Figure 5.

695

696

697

698

699

700

701

702

703

704

705

706

707

708

709

710 


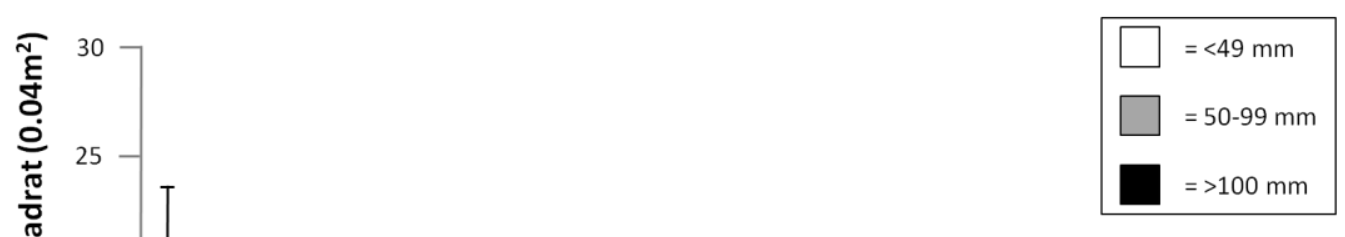

711

Salinity

712

713 Figure 6. 